\title{
New familial cases of karyomegalic interstitial nephritis with mutations in the FAN1 gene
}

\author{
Imen Rejeb ${ }^{1 *+} @$, Mouna Jerbi ${ }^{2,3,4 \dagger}$, Houweyda Jilani ${ }^{1,4}$, Hanène Gaied ${ }^{2,3,4}$, Yasmina Elaribi ${ }^{1,4}$, Syrine Hizem ${ }^{1,4}$, \\ Raja Aoudia, ${ }^{3,4}$, , Hafedh Hedri ${ }^{3,4,5}$, Chiraz Zaied ${ }^{6}$, Salwa Abid ${ }^{6}$, Hassen Bacha ${ }^{6}$, Taieb BenAbdallah ${ }^{4,5}$, \\ Lamia BenJemaa ${ }^{1,4}$ and Rim Goucha $2,3,4$
}

\begin{abstract}
Background: Karyomegalic interstitial nephritis (KIN) is a rare disease entity first described by Burry in 1974. The term KIN was introduced by Mihatsch et al. in 1979. KIN is characterized by chronic tubulointerstitial nephritis associated with enlarged tubular epithelial cell nuclei, which leads to a progressive decline of renal function. The prevalence of this disease is less than $1 \%$ of all biopsies, and its pathogenesis is unclear. KIN results from mutations in FAN1 (FANCD2/FANCl-Associated Nuclease 1), a gene involved in the DNA damage response pathway, particularly in the kidney. In this study, we report two Tunisian consanguineous families with KIN caused by mutations in the FAN1 gene.

Methods: Direct sequencing of the coding regions and flanking intronic sequences of the FAN1 gene was performed in three affected members. Three prediction programs (Polyphen-2 software, SIFT, and MutationTaster) were used to predict the functional effect of the detected variations.

Results: Two causative frameshift variants in the FAN1 gene were identified in each family: The previously described frameshift mutation c.2616delA (p.Asp873ThrfsTer17) and a novel mutation c.2603delT (p.Leu868ArgfsTer22) classified as "pathogenic" according to the American College of Medical Genetics and Genomics (ACMG) guidelines.

Conclusion: To our best knowledge, this is the first Tunisian study involving familial cases of KIN with mutations in the FAN1 gene. We hypothesize that these findings can expand the mutational spectrum of KIN and provide valuable information on the genetic cause of KIN.
\end{abstract}

Keywords: Karyomegalic interstitial nephritis, Chronic tubulointerstitial nephritis, FAN1 gene, Frameshift variants

\section{Background}

Karyomegalic interstitial nephritis (KIN) is a rare disease that was first described by Burry [1] and given this term later by Mihatsch et al. [2]. A history of recurrent respiratory infections and progressive renal failure was

*Correspondence: imen_rejeb@yahoo.fr; imen.rejeb@rns.tn ${ }^{\dagger}$ Imen Rejeb and Mouna Jerbi contributed equally to this work

1 Service des Maladies Congénitales et Héréditaires, CHU Mongi Slim La Marsa, La Marsa, Tunisia

Full list of author information is available at the end of the article described. Since then, approximately 50 cases of KIN and 12 families have been reported in the literature [3-5].

KIN is characterized by chronic tubulointerstitial nephritis associated with enlarged tubular epithelial cell nuclei, leading to the progressive decline of renal function. Its prevalence is below $1 \%$ of all biopsies [6]. Its pathogenesis is unclear yet.

Mutations in the FAN1 gene involved in the DNA damage response pathway, including the kidney, have been reported in 2012 as causative in familial cases of KIN [4]. These findings allowed us to highlight the potential 
link between defective DNA repair and chronic kidney disease progression. This is the first reported Tunisian study involving familial cases of KIN with mutations in the FAN1 gene.

\section{Methods}

\section{Case presentation}

Two consanguineous families from the north of Tunisia (Fig. 1) were referred to our nephrology department because of impaired renal function caused by KIN.

\section{Microscopy analysis}

The renal biopsies of the patients were examined by light microscopy (Nikon Eclipse E400 Research Microscope) using conventional staining methods and immunofluorescence. The photos were taken using the Nikon Coolpix 4500 4MP Digital camera.

For the electron microscopy we used a Jeol 1010 transmission electron microscope operated at $80 \mathrm{kV}$.

\section{Family $A$}

Proband IV-2 Born in 1963, he was admitted for convulsions. A chronic renal failure linked to tubular nephropathy with hepatic cytolysis and cholestasis was suspected. Renal biopsy was not performed because of small kidneys. The diagnosis of end-stage renal disease (ESRD) due to tubulointerstitial nephritis was retained.

The serum creatinine level was $900 \mu \mathrm{mol} / \mathrm{L}$, the estimated glomerular filtration rate (eGFR) was $9.9 \mathrm{~mL} /$ $\mathrm{min} / 1.73 \mathrm{~m}^{2}$, and proteinuria was $0.25 \mathrm{~g} / 24 \mathrm{~h}$.
The patient received a living renal transplant from his wife (patient IV-1), a second-degree cousin. His renal function was still normal 18 years later.

Patient IV-7 Born in 1969, the disease was discovered during a kidney donor checkup. A kidney failure was detected with serum creatinine level at $161 \mu \mathrm{mol} / \mathrm{L}$ and eGFR at $69.4 \mathrm{~mL} / \mathrm{min} / 1.73 \mathrm{~m}^{2}$. Proteinuria was absent in the 24-h urine dosage.

Renal biopsy revealed KIN. The obtained renal tissue contained 21 glomeruli: 7 were sclerotic and atrophic and 14 were normal. The epithelial cells were atrophic or normal. Proximal or distal tubules contained giant nuclei with irregular nuclear membrane and rare inclusions in 1-2 nuclei. The interstitial tissue showed fibrosis with mononuclear infiltrations. Immune deposits were not detected in immunofluorescence. Electron microscopy showed giant karyomegalic nuclei in the epithelial cells of proximal tubules that were severely enlarged, polymorphic and lobulated. The nuclear membrane had intense invagination and lobulation (Fig. 2).

The patient received a living renal transplant and was deceased from pulmonary embolism.

Patient IV-11 Born in 1974, he consulted for a kidney donor checkup. Tubulointerstitial nephritis with chronic renal failure was diagnosed. Renal biopsy was impossible to do because of small kidneys.

Serum creatinine level was at $197 \mu \mathrm{mol} / \mathrm{L}$, eGFR at $53.38 \mathrm{~mL} / \mathrm{min} / 1.73 \mathrm{~m}^{2}$.

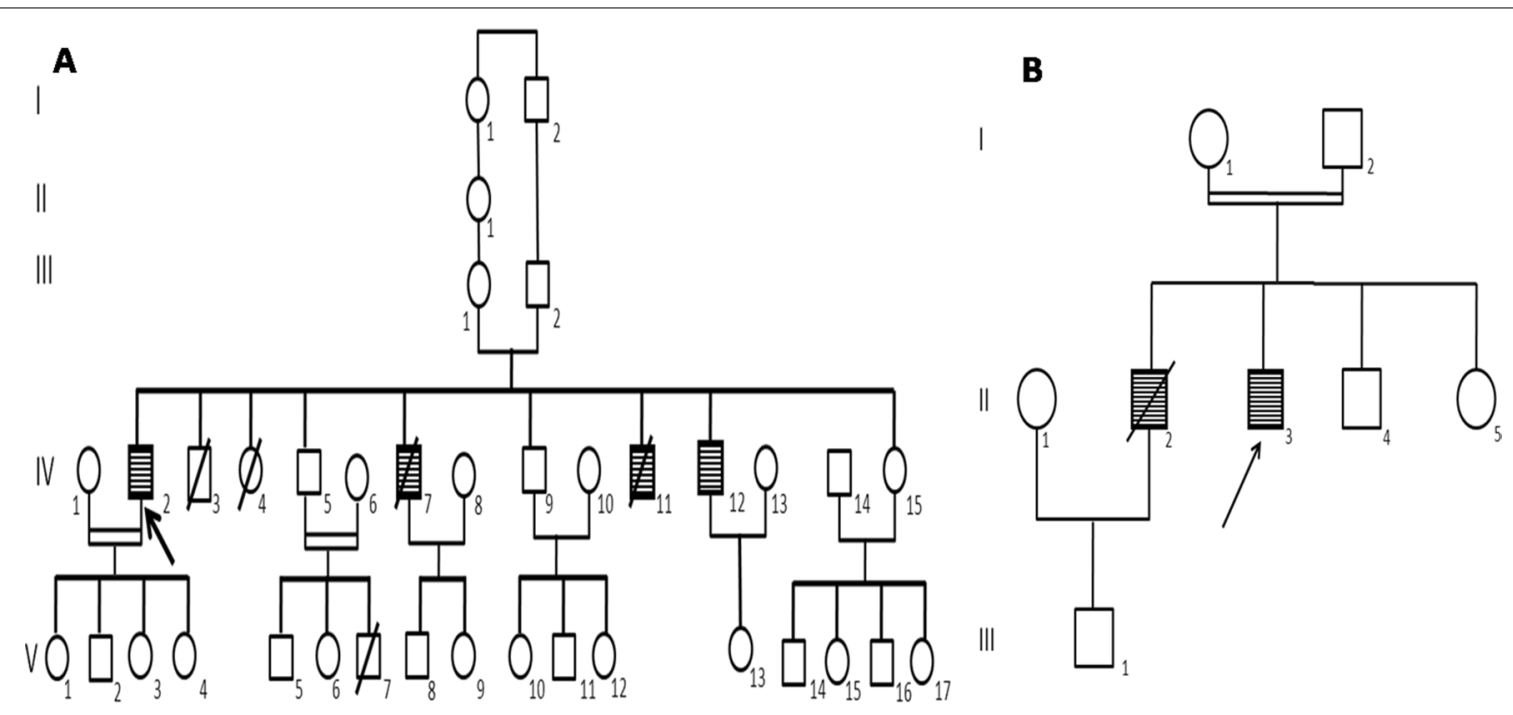

Karyomegalic interstitial nephritis

Fig. 1 a Pedigree of the family A, $\mathbf{b}$ Pedigree of the family $Z$ 

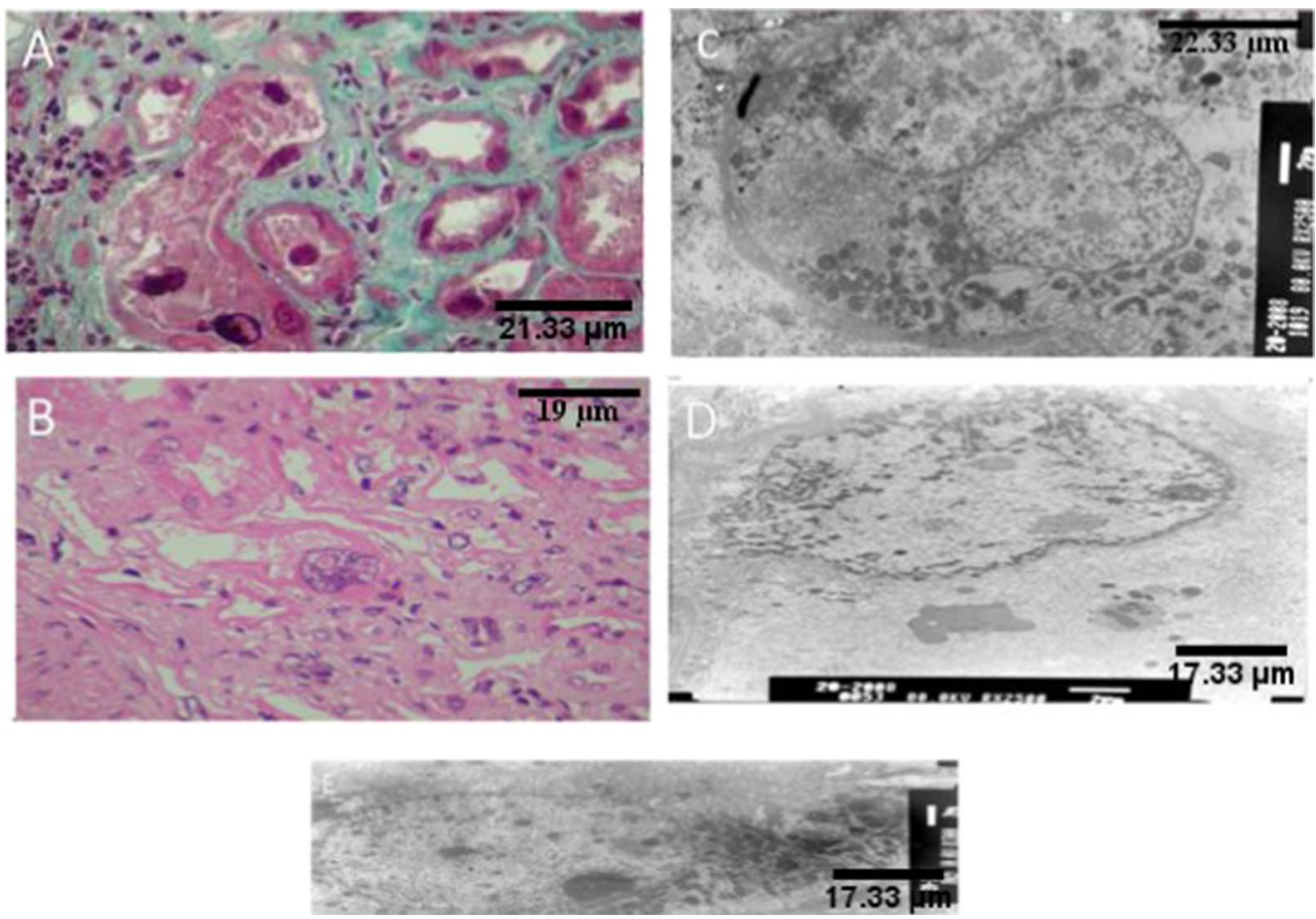

Fig. 2 Renal histology in Patient IV-7 and Patient IV-12 in family A. a Renal biopsy, Masson's trichroma (magnification $\times$ 400). Proximal tubules with giant nuclei, irregular nuclear membrane (Patient IV-7). b Renal biopsy, hematoxylin and eosine stain (magnification $\times 200$ ). Giant nuclei with irregular nuclear membrane (Patient IV-7). c, d Renal biopsy, electron microscopy. Giant karyomegalic nuclei with irregular nuclear membrane (Patient IV-7). e Renal biopsy, electron microscopy. Giant karyomegalic nuclei of epithelial cells of proximal tubules (Patient IV-12)

The patient underwent hemodialysis for 3 years and was deceased from severe infection.

Patient IV-12 Born in 1976, he was admitted to the nephrology department for an incidental finding of renal failure, after the discovery of nephropathy in his two brothers (Patients IV-2 and IV-11).

Serum creatinine level was at $141 \mu \mathrm{mol} / \mathrm{L}$, eGFR was at $65.9 \mathrm{~mL} / \mathrm{min} / 1.73 \mathrm{~m}^{2}$ and proteinuria was absent in the 24-h urine dosage.

Renal biopsy showed KIN. The obtained renal tissue contained 39 glomeruli: 13 were sclerotic and atrophic and the remaining 26 were normal. The interstitial tissue showed a fibrosis band and atrophic tubules, giant nuclei of tubular epithelium with irregular nuclear membrane. Immune deposits were not detected in immunofluorescence. Electron microscopy revealed epithelial cells of proximal tubules with karyomegalic nuclei. The nucleoli had variable size and polymorphism. The tubular basement membranes were occasionally thickened without demonstrable osmiophilic deposits (Fig. 2).

Liver function test revealed cytolysis and cholestasis in patient IV-2 and IV-12. Patient IV-7 had cholestasis.
Liver biopsy performed in patient IV-7 showed no specific pathology.

Urinalysis indicated negative proteinuria, hematuria, and glycosuria for IV-2 and IV-12. In patient IV-7, urinalysis showed negative hematuria and glycosuria, and trace proteinuria. Leukocyturia $2+$ was found in patients IV-2 and IV-7.

Viral serology, serum ANCA (Antineutrophil cytoplasmic antibody), ANA (Antinuclear antibody) immunofixation, and free light chain levels were within the normal range for patients IV-2, IV-7, and IV-12.

Available laboratory parameters and clinical data are summarized in Table 1.

\section{Family $Z$}

The second family was also a consanguineous family from the north of Tunisia, with eight individuals who did not live in rural areas (Fig. 1b).

Patient II-2 He was diagnosed with ESRD at the age of 31 and treated by peritoneal dialysis. He was deceased from pulmonary tuberculosis four years later. 


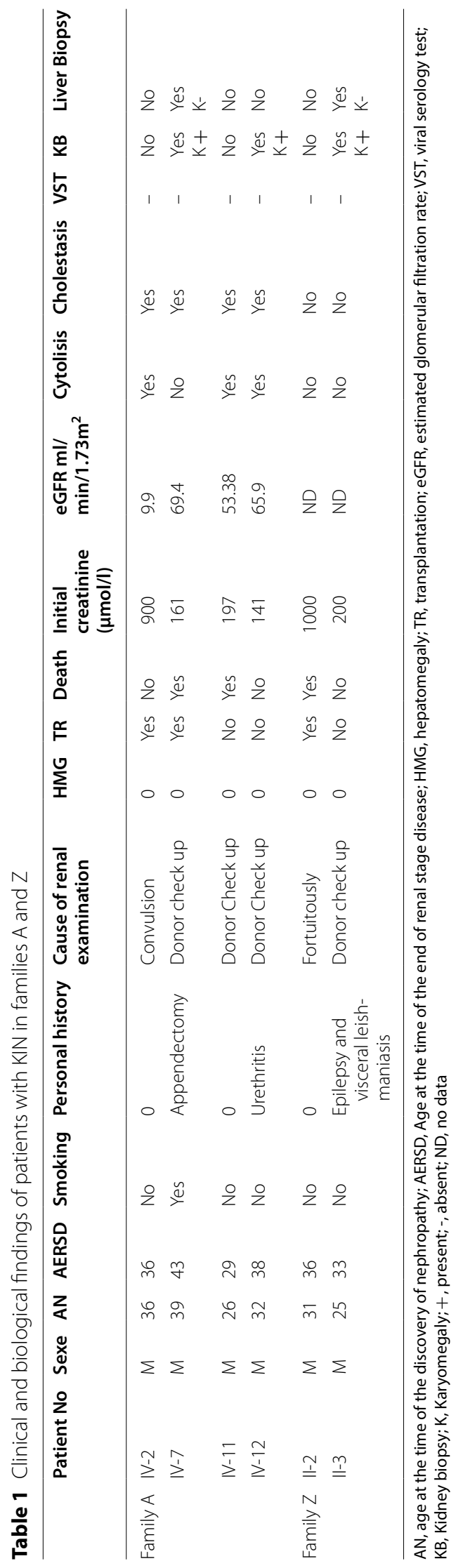


Patient II-3 He was admitted for a kidney donor checkup. He had a history of epilepsy and visceral leishmaniasis. Kidney failure with serum creatinine level at $200 \mu \mathrm{mol} / \mathrm{L}$ was discovered. Renal biopsy revealed KIN (Fig. 3).

The urine dipstick test and blood pressure of the other family members were normal. The liver function test did not reveal cytolysis nor cholestasis.

Table 1 summarizes the available laboratory parameters and clinical data.

The discovery of two members with KIN confirmed by renal biopsy (Patients IV-7 and IV-12) and two others with ESRD (Patients IV-2 and IV-11) in family A due to tubulointerstitial nephropathy in four siblings was highly suggestive of hereditary chronic interstitial nephropathy.

\section{Mutation screening of the FAN1 gene by direct sequencing}

Based on these clinical findings, and after written consent, sequencing of the FAN1 gene was performed for each family proband (Patient IV-2 of family A and Patient II-3 of family Z).

Genomic DNA was extracted from peripheral blood leukocytes by the standard proteinase-K extraction.
For FAN1 gene analysis, the coding regions (13 exons, GenBank accession number NM_014967.4) and flanking intronic sequences were amplified by PCR using genomic DNA according to the PCR protocol described by Zhou et al. [4].

PCR products were directly sequenced with the Big Dye Terminator ready reaction kit (PE Applied Biosystems) on an Applied Biosystems SeqStudio Genetic Analyzer. Base-calling was performed by using Sequencing analysis software v7.0.

The reference sequence was obtained from the UCSC Human Genome Browser (http://www.genom.ucsc.edu; FAN1: NM_014967.4).

The results were analyzed using Sequencher 5.0 Demo. Three programs (Polyphen-2 software, SIFT, and MutationTaster) were used to predict the functional effect of the detected variations.

\section{Results}

Genetic analysis by Sanger sequencing of FAN1 of each family proband allowed us to identify two different mutations in exon 12:
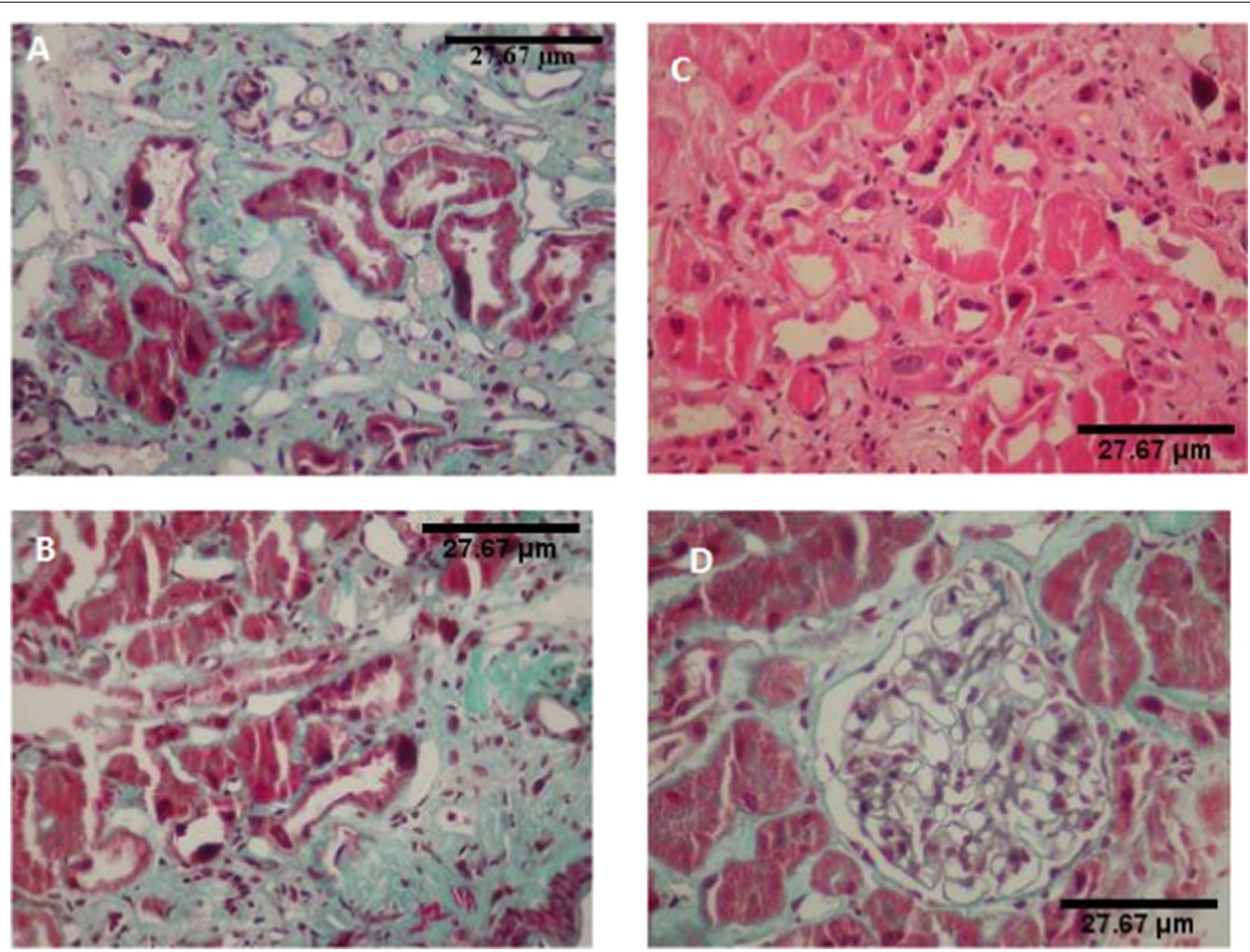

Fig. 3 Renal histology in Patient II 3 in family Z. a Renal biopsy, Masson's trichroma (magnification × 200). Giant nuclei of tubular epithelium. b Renal biopsy, Masson's trichroma (magnification × 400). Giant nuclei of tubular epithelium, moderately inflammatory interstitial fibrosis. c Renal biopsy. Hematoxylin and eosine stain (magnification $\times 200$ ). Karyomegalic nephropathy. $\mathbf{d}$ Renal biopsy. Masson'strichroma (magnification $\times 400)$. Normal glomerulus 
In patient IV-2 of Family A, we found a homozygous frameshift mutation due to a one-basepair deletion (c.2616delA), resulting in the appearance of a premature STOP codon (p.Asp873ThrfsTer17) (Fig. 4).

The identified mutation was tested for familial segregation in IV-5, IV-12, and IV-15. The observed mutation was found in a homozygous state in the affected brother (IV-12) and was absent in the healthy brother (IV-5). The parents of the proband and his sister (IV-15) were heterozygous for the mutation. The variation was found to segregate with the phenotype and in obligate carriers.

Regarding patient II-3 of Family Z, we found a homozygous frameshift mutation due to a one-base-pair deletion (c.2603delT), resulting in the appearance of a premature STOP codon (p. (Leu868ArgfsTer22)) (Fig. 4). This mutation was reported neither in the literature nor in online databases as polymorphism. The three prediction programs (PolyPhen2, SIFT, and MutationTaster) showed a consistent result of the deleterious effect of this mutation. The parents of the proband of Family $\mathrm{Z}$ were heterozygous for the mutation; the rest of the family was not tested.

\section{Discussion}

Karyomegalic interstitial nephritis (KIN) is a rare genetic disease that was first described by Burry [1] and given this term later by Mihatsch et al. [2], who described two siblings and an unrelated third patient with progressive chronic renal failure disease.
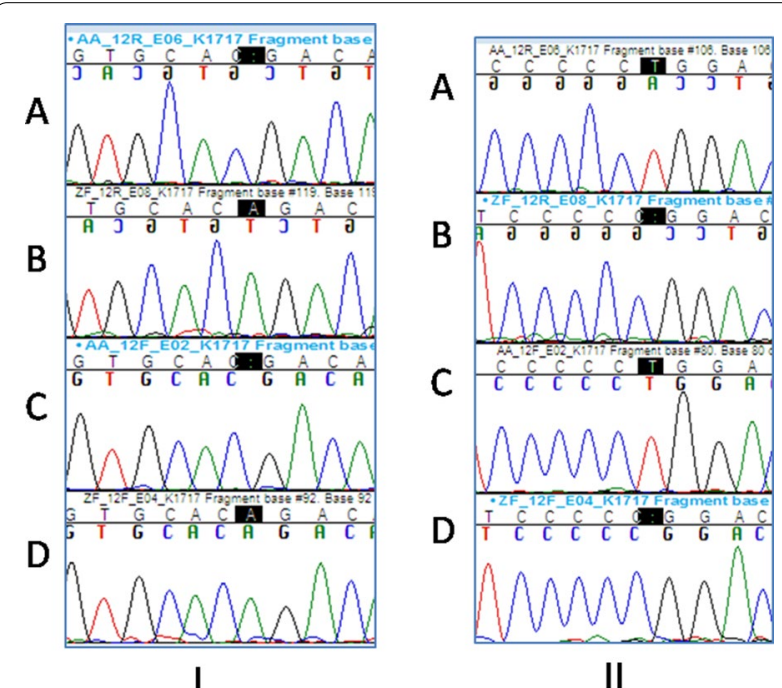

Fig. 4 I: Electropherogram showing the mutation c.2616delA found in family $\mathrm{A}$ (a, c mutation found in patient IV-2, b, d wildtype). II: Electropherogram showing the mutation c.2603delT found in family Z (a, c wildtype, b, d mutation found in patient II-3)
Patients with KIN usually show progressive renal dysfunction, haematoproteinuria, and a family history of renal disease. They frequently develop recurrent respiratory infections in their 20s [2] that were not noticed in our patients.

Transient elevations of liver enzymes were observed in our patients (Table 1 ) as described in others $[2,8,9]$.

An end-stage renal failure appears before 50 years of age [3]. In our series of patients, the mean age at first documentation of nephropathy was 26.83 years. In the literature, the average age is 36.42 years. Indeed, most patients, including ours, developed a progressive renal failure beginning in the third decade of life. The evolution to ESRD is usually at an age of 37.22 years ( 36.5 years in our series).

Karyomegaly is not kidney-specific. Mihatsch et al. [2], reported biopsy specimens of several organs of a patient and the autopsy of one patient that disclosed polymorphic enlarged nuclei in epithelial and mesenchymal cells of the kidneys and many other organs, i.e. smooth muscle cells of the intestine, alveolar epithelial cells, brain astrocytes, bile duct epithelium and, Kupffer cells. In our cases, one liver biopsy was performed and did not show karyomegalic cell nuclei, which suggests a predominance of renal sensitivity that is probably due to a specific repair mechanism in kidney tubular cells.

In 2012 Zhou et al. [4] identified recessive mutations in the FAN1 gene as causing KIN. To date, to our knowledge, 12 families with an autosomal recessive inheritance have been reported with FAN1 mutations.

By taking into account these results, we sequenced the FAN1 gene for some of the affected members of our families. Sequencing allowed us to identify 2 different mutations in the exon 12 for each family.

The c.2616delA mutation resulting in a premature STOP codon (p.Asp873ThrfsTer17) was detected in Family A (Patients IV-7 and IV-12) (Fig. 4). This mutation was previously reported in a family with KIN by Zhou et al. [5] and recently by Dash et al. [7].

A new homozygous frameshift mutation (c.2603delT) resulting in a premature STOP codon (p.Leu868ArgfsTer22) was detected in Family Z (Patient II-3) (Fig. 4).

To the best of our knowledge, nine mutations in the exon 12 of FAN1 gene were reported in the literature in families with KIN [4, 7], our mutations are the newest ones (Table 2).

The most recurrent mutation is c.2616delA found in French [3, 4], Spanish [4], and recently in Bulgarian [7] families (Table 2). Family A reported here is the fifth family. Zhou et al. [4] considered this mutation as a European founder mutation. In North African countries, especially in Tunisia, there is a great heterogeneity of ancestors. We 
Table 2 Review of mutations reported in the FAN1 gene

\begin{tabular}{|c|c|c|c|c|c|}
\hline References & Ethnic origin & Nucleotide alteration & Deduced protein change & Exon/intron (state) & $\begin{array}{l}\text { Parental } \\
\text { consan- } \\
\text { guinity }\end{array}$ \\
\hline Zhou et al. [4] & French & $\begin{array}{l}\text { c.1234+2T>A } \\
\text { c.2036_7delGA }\end{array}$ & $\begin{array}{l}\text { Splice site } \\
\text { p.Arg679Thrfs*5 }\end{array}$ & $\begin{array}{l}2 \text { (het) } \\
7 \text { (het) }\end{array}$ & No \\
\hline Zhou et al. [4] & French & $\begin{array}{l}\text { C. } 1234+2 T>A \\
\text { c. } 2245 C>T\end{array}$ & $\begin{array}{l}\text { Splice site } \\
\text { p.Arg749* }\end{array}$ & $\begin{array}{l}2 \text { (het) } \\
9 \text { (het) }\end{array}$ & No \\
\hline Zhou et al. [4] & French & $\begin{array}{l}\text { c. } 1375+1 G>A \\
\text { c. } 2616 \text { delA }\end{array}$ & $\begin{array}{l}\text { Splice site } \\
\text { p.Asp873Thrfs*17 }\end{array}$ & $\begin{array}{l}3 \text { (het) } \\
12 \text { (het) }\end{array}$ & No \\
\hline Zhou et al. [4] & German & $\begin{array}{l}\text { c. } 1606 C>T \\
\text { c. } 2786 A>C\end{array}$ & $\begin{array}{l}\text { p.Arg536* } \\
\text { p.Gln929Pro }\end{array}$ & $\begin{array}{l}5 \text { (het) } \\
12 \text { (het) }\end{array}$ & No \\
\hline Zhou et al. [4] & German & $\begin{array}{l}\text { c.1606C }>T \\
\text { c. } 2878 G>A\end{array}$ & $\begin{array}{l}\text { p.Arg536* } \\
\text { p.Asp960Asn }\end{array}$ & $\begin{array}{l}5 \text { (het) } \\
13 \text { (het) }\end{array}$ & No \\
\hline Zhou et al. [4] & $\begin{array}{l}\text { New Zealand } \\
\text { Maori }\end{array}$ & c. $2120 \mathrm{G}>\mathrm{A}$ & p.Trp707* & 8 (hom) & distant? \\
\hline Zhou et al. [4] & Spanish & c.2616delA & p.Asp873Thrfs*17 & 12 (hom) & No \\
\hline Zhou et al. [4] & Swiss & $\begin{array}{l}\text { c. } 2611 \mathrm{~T}>\mathrm{C} \\
\text { c.2878G }>\mathrm{A}\end{array}$ & $\begin{array}{l}\text { p.Cys871Arg } \\
\text { p.Asp960Asn }\end{array}$ & $\begin{array}{l}12 \text { (het) } \\
13 \text { (het) }\end{array}$ & No \\
\hline Zhou et al. [4] & USA & $\begin{array}{l}\text { c.2774_5delTT } \\
\text { c. } 2810 \mathrm{G}>A\end{array}$ & $\begin{array}{l}\text { p.Leu925Profs*25 } \\
\text { p.Gly937Asp }\end{array}$ & $\begin{array}{l}12 \text { (het) } \\
13 \text { (het) }\end{array}$ & No \\
\hline Isnard et al. [3] & French & c.2616delA & p.Asp873Thrfs*17 & 12 (hom) & ND \\
\hline Dash et al. [6] & Bulgarian & $\begin{array}{l}\text { c.1102C>T } \\
\text { c.2616delA }\end{array}$ & $\begin{array}{l}\text { p.Gln368* } \\
\text { p.Asp873Thrfs*17 }\end{array}$ & $\begin{array}{l}2 \text { (het) } \\
12 \text { (het) }\end{array}$ & ND \\
\hline Koshy et al. [5] & Indian & $\begin{array}{l}\text { c. } 1356 T>G \\
\text { c. } 1369 C>T\end{array}$ & $\begin{array}{l}\text { p.Asn452Lys } \\
\text { p.Gln457* }\end{array}$ & $\begin{array}{l}4 \text { (het) } \\
4 \text { (het) }\end{array}$ & ND \\
\hline Present study Family A & Tunisian & c.2616delA & p.Thr872Thrfs*17 & 12 (hom) & Yes \\
\hline Present study Family Z & Tunisian & c.2603delT & p.Leu868Argfs*21 & 12(hom) & Yes \\
\hline
\end{tabular}

Hom, homozygous; Het, heterozygous; ND, no data

can suggest that this is a founder mutation only by comparing of haplotypes between the families harboring the same mutation to distinguish whether it derives from an older or more recent single mutational event or whether it has arisen independently more than once.

FAN1 encodes Fanconi anemia-associated nuclease 1 (FAN1), which interacts with Fanconi Anemia Complementation group D2 (FANCD2) and Fanconi Anemia Complementation group I (FANCI), forming the Fanconi Anemia core complex. This complex is recruited at the sites of Interstrand DNA crosslinks (ICL) lesions [10-13].

Zhou et al. suggest that biallelic mutations in FAN1 cause KIN instead of FA [5]. The cause of the karyomegaly in KIN is not yet understood, but according to Lachaud et al. [14], defective ICL repair can cause karyomegaly.

Chaki et al. suggested that there is a link between degenerative kidney diseases and defective DNA damage repair [15].

More recently, Law et al. [16] reported the first case of a patient with concurrent leukocyte chemotactic factor 2 amyloidosis (ALECT2) and KIN caused by a novel deletion in FAN1. This highlights the importance of renal biopsy in chronic kidney disease of unclear etiology.

\section{Conclusions}

In conclusion, our study is the first Tunisian report of familial cases of KIN with mutations involving the FAN1 gene, which plays a crucial key role in DNA repair. The FAN1 gene should be screened in families with more than one case with KIN. Familial counseling must be offered to the rest of the families for allograft planning.

\section{Abbreviations}

KIN: Karyomegalic interstitial nephritis; FAN1: FANCD2/FANCI-Associated Nuclease 1; ESRD: End-stage renal disease; eGFR: Estimated glomerular filtration rate; ANCA: Antineutrophil cytoplasmic antibody; ANA: Antinuclear antibody; FAN1: FANCD2/FANCI-Associated Nuclease 1; FANCD2: Fanconi Anemia Complementation group D2; FANCl: Fanconi Anemia Complementation group I; DDR: DNA damage response; ICL: Interstrand crosslinks; FA: Fanconi anemia; ZNF423: Zinc Finger Protein 423; CEP164: CentrosomalProtein 164; ALECT2: Leukocyte chemotactic factor 2 amyloidosis.

\section{Acknowledgements}

We are grateful to the families who contributed to this study.

\section{Authors' contributions}

IR contributed to sample collection, analyzed clinical data, performed Sanger sequencing and segregation analysis, and drafted the paper; MJ and HG contributed to the collection of clinical data; $\mathrm{HJ}, \mathrm{YE}$, and $\mathrm{SH}$ contributed to genetic counseling; $\mathrm{RA}, \mathrm{HH}$, and TB analyzed the renal biopsies; CZ, SA, and $\mathrm{HB}$ performed the laboratory investigations, LB and RG designed and initiated 
the study, monitored data collection and analysis for the study and revised the paper. All authors read and approved the final manuscript.

\section{Funding}

This research did not receive any specific grant from funding agencies in the public, commercial, or not-for-profit sectors.

\section{Availability of data and materials}

The principal datasets generated and/or analyzed during the current study are included in the published article. The datasets used in this study are available from the corresponding author by request. The sequence data are available in the NCBI SRA under the accession number PRJNA727732 (https://www.ncbi. nIm.nih.gov/Traces/study/?acc=PRJNA727732).

\section{Declarations}

\section{Ethics approval and consent to participate}

All procedures performed in the present study were approved by The Ethical Review Committee of Mongi Slim Hospital (La Marsa, Tunisia) and were also in accordance with the Declaration of Helsinki. Written informed consent was obtained from all individuals.

\section{Consent for publication}

Written consent has been obtained from all participants included in the study.

\section{Competing interests}

The authors declare that they have no competing interests.

\section{Author details}

${ }^{1}$ Service des Maladies Congénitales et Héréditaires, CHU Mongi Slim La Marsa, La Marsa, Tunisia. ${ }^{2}$ Service de Néphrologie, CHU Mongi Slim La Marsa, La Marsa, Tunisia. ${ }^{3}$ Laboratory of Renal Pathology LROOSP01, Tunis, Tunisia. ${ }^{4}$ Faculty of Medicine, University Tunis El Manar, Tunis, Tunisia. ${ }^{5}$ Department of Internal Medicine, Charles Nicolle Hospital, Tunis, Tunisia. ${ }^{6}$ Faculty of Dentistry, Monastir, Tunisia.

Received: 1 October 2020 Accepted: 7 June 2021

Published online: 14 June 2021

\section{References}

1. Burry AF. Extreme dysplasia in renal epithelium of a young woman dying from hepatocarcinoma. J Pathol. 1974;113(3):147-50.

2. Mihatsch MJ, Gudat F, Zollinger HU, Heierli C, Thölen H, Reutter FW. Systemic Karyomegaliy associated with chronic interstitial nephritis. A new disease entity? Clin Nephrol. 1979;12(2):54-62.
3. Isnard P, Rabant M, Labaye J, Antignac C, Knebelmann B, Zaidan M. Karyomegalic interstitial nephritis: a case report and review of the literature. Medicine (Baltimore). 2016;95(20):e3349.

4. Zhou W, Otto EA, Cluckey A, Airik R, Hurd TW, Chaki M, et al. FAN1 mutations cause karyomegalic interstitial nephritis, linking chronic kidney failure to defective DNA damage repair. Nat Genet. 2012;44(8):910-5.

5. Koshy PJ, Sudhakar DVS, Anupama SH, Mathew M, Parthasarthy R, Thangaraj K, et al. Novel homozygous FAN1 mutation in a familial case of karyomegalic interstitial nephritis. Indian J Nephrol. 2020;30(4):283-5. https://doi.org/10.4103/ijn.IJN_278_19.

6. Uz E, Bayram Y, Haltas H, Bavbek N, Kanbay M, Guz G, et al. Karyomegalic tubulointerstitial nephritis: a rare cause of chronic kidney disease. Nephro-Urol Mon Online. 2011;3(3):201-3.

7. Dash J, Saudan P, Paoloni-Giacobino A, Moll S, de Seigneux S. Case report: a 58 -year-old man with small kidneys and elevated liver enzymes. BMC Nephrol. 2020;21(1):107. https://doi.org/10.1186/s12882-020-01762-4.].

8. Palmer D, Lallu S, Matheson P, Bethwaite P, Tompson K. Karyomegalic interstitial nephritis: a Pitfallin urine cytology. Diagn Cytopathol. 1997;35:179-82.

9. Vadiaka M, Sotsiou F, Koufos C. A case of systemic karyomegaly associated with interstitial nephritis. Ann Med Interne. 1998;149(5):291-4.

10. Liu T, Ghosal G, Yuan J. FAN1 acts with FANCI-FANCD2 to promote DNA interstrand cross-link repair. Science. 2010;329:693-6.

11. Kratz K, Schöpf B, Kaden S, Sendoel A, Eberhard R, Lademann C, et al. Deficiency of FANCD2-associated nuclease KIAA1018.FAN1 sensitizes cells to interstrand crosslinking agents. Cell. 2010;142:77-88.

12. Mackay C, Déclais AC, Lundin C, Agostinho A, Deans AJ, MacArtney TJ, et al. Identification of KIAA1018.FAN1, a DNA repair nuclease recruited to DNA damage by monoubiquitinated FANCD2. Cell. 2010;142:65-76.

13. Smogorzewska A, Desetty R, Saito TT, Schlabach M, Lach FP, Sowa ME, et al. A genetic screen identifies FAN1, a Fanconi anemia-associated nuclease necessary for DNA interstrand crosslink repair. Mol Cell. 2010;39:36-47.

14. Lachaud C, Slean M, Marchesi F, Lock C, Odell E, Castor D, et al. Karyomegalic interstitial nephritis and DNA damage-induced polyploidy in Fan1 nuclease-defective knock-in mice. Genes Dev. 2016;30(6):639-44.

15. Chaki M, Airik R, Ghosh AK, Giles RH, Chen R, Slaats GG, Wang H, et al. Exome capture reveals ZNF423 and CEP164 mutations, linking renal ciliopathies to DNA damage response signaling. Cell. 2012;150(3):533-48.

16. Law S, Gillmore J, Gilbertson JA, Bass P, Salama AD. Karyomegalic interstitial nephritis with a novel FAN1 gene mutation and concurrent ALECT2 amyloidosis. BMC Nephrol. 2020;21(1):74. https://doi.org/10.1186/ s12882-020-01733-9.

\section{Publisher's Note}

Springer Nature remains neutral with regard to jurisdictional claims in published maps and institutional affiliations.
Ready to submit your research? Choose BMC and benefit from:

- fast, convenient online submission

- thorough peer review by experienced researchers in your field

- rapid publication on acceptance

- support for research data, including large and complex data types

- gold Open Access which fosters wider collaboration and increased citations

- maximum visibility for your research: over 100M website views per year

At BMC, research is always in progress.

Learn more biomedcentral.com/submissions 